\title{
Affordability of Water Service from Perspective of Water Security of Community in Bekasi District
}

\author{
Ninin Gusdini ${ }^{1} \quad$ M. Januar J Purwanto ${ }^{2} \quad$ Kukuh Murtilaksono $^{3} \quad$ dan Kholil ${ }^{4}$ \\ 1. Environmental Engineering Sahid University \\ 2.Department of Civil and Environmental Engineering -IPB \\ 3.Department of Soil Science and Land Resources Management -IPB \\ 4.Environmental Engineering Program -Usahid
}

\begin{abstract}
Affordability of society towards the cost of water service contributes to the selection of water source they use. Non-fulfillment of affordability aspect in accordance with the policy Regulation No. 23/2006, causing at least two things: the reduction of social welfare and security threats to the quality of water consumed by public. The affordability is calculated based on the costs used to meet water needs and family incomes. The analysis results in Bekasi show that social income of $<\mathrm{Rp} 3,000,000$ both use piping and non-piping service, the burden of their monthly expenditure to meet the water needs above the standard set by the government amounted to $4 \%$ of family income.
\end{abstract}

Keywords: Affordability, Water, Piping service, Non-piping service, Welfare

DOI: $10.7176 / \mathrm{JRDM} / 60-05$

Publication date:October $31^{\text {st }} 2019$

\section{Introduction}

Clean water is a major factor in human life and development of economic sector (Pinto F S 2015). Insufficiency for clean water affects the health and welfare of the community. Clean water that is insufficiency and not in accordance with the required quality has caused 842.000 deaths and billions of cases of diarrhea per year (Clasen $\mathrm{T}$ 2014). This problem often encountered in developing and underdeveloped countries, because it has not fully communities underserved with clean water supply facilities in accordance with the standard. To minimize this problem, the government must ensure the availability and security of water quality for the community (Lee E J, 2005; Hunter P R, 2010; Pinto F S, 2015).

Piping services system can minimize the contamination of clean water that will be consumed by public. This system managed by the regional water company or private. However on the other hand, the use of the piping system in water services provide the consequences in term of financing, because in running this system, it requires installation investment, piping, and maintenance. The community who use this service has to pay services. Costs incurred by the community to meet the needs of this water should be comparable with the income they receive. The expenses to meet the needs of water above the standard value that set by the government through Regulation No. $23 / 2006$ of $4 \%$ of income can threaten the decline in welfare of the community.

Affordability of the community in fulfilling the needs of clean water may be one indicator of whether the service water supplied can be sustained or not (Martins R, 2016). When financing in fulfilling the needs of healthy water exceeds the ability of public, hence public will face two choices that still meet their water needs by utilizing the services of healthy water with the consequence of having to pay relatively more expensive or switch utilizing other water sources that are more affordable, although forcefully must receive the quality or quantity of water that is not according to standards and requirements. Therefore, the government needs to intervene to lower the cost of fulfillment the water needs of community and ensure its availability both in quality and quantity.

Bekasi District is one district that is growing rapidly, as affected by the development of Bekasi and Jakarta City. Bekasi District is dominated by rural areas as many as 180 area. The economic level is still dominated by middle-down economic levels, except in the central region and capital city or around the area of Cikarang. Therefore, the welfare of the community is very sensitive and vulnerable to charges fulfillment of community water supply. Geographically, Bekasi District has coastal areas bordering the sea which is situated in the northern part, and agricultural areas in the south. It will certainly affect the water service system is needed and costs to be incurred in the fulfillment. The more difficult or complex water services, the costs to be incurred to meet their needs will be higher.

In this study, it will be analyzed affordability condition and phenomena of the community against various types of water services, either through piping and non-piping services. Moreover, it will be revealed the actual value of the costs incurred by the community to meet the needs of their water. The results of this study can be utilized for the Government especially Bekasi District Government to formulate the strategies and policies to ensure the water needs of community as an affordable, safe and sustainable. 


\section{Methods}

Data and information used in this study were obtained from the survey results of households in Bekasi, BPS (Central Bureau of Statistics) and PDAM (Regional Water Company) as an institution with the authority in providing clean water community. Sampling for households was carried out purposively with reference to development areas in Bekasi District defined in the RTRW (Spatial and Regional Plan) Bekasi District. Development areas are divided into four groups, namely: (1) Center for continued growth in the central zone, represented by the South Tambun and Cikarang Barat and Cikarang Selatan (2) The central government and the growth center of the southern zone, represented by the Central Cikarang, Setu and Cibarusah (3) areas of food security that is in the eastern region represented by Sukatani, Sukakarya, and Karangbahagia (4) Center north zone growth represented by Tarumajaya, Muaragembong and Babelan. Each region development represented by development centers and water service area that is already good and is still poor. The samples used in this study were 250 households, which are composed of piping and non-piping services.

Affordability of water services in this study in term of the ratio between the costs incurred by society to meet the needs of clean water toward the people's income (Regulation No. 23 of 2006; Sawkins J 2005; Rita M, 2010). The proportion value of expenditure on the water to the family income varies for each State, for Indonesia by Regulation No. 23 of 2006 was set at $4 \%$.

The amount of expenditure to meet the water needs is calculated in the family unit. For users of the cost of piping services of water is calculated based on the average water bill per month plus the cost of purchasing a gallon of water if it is used. For people who use non-piping services, water expenditure is calculated based on the purchase of water gallons/litter per month and the estimated cost of the electricity used to pump water in one month. While the revenue is calculated based on the average aggregate income per family.

\section{Results and discussion}

\subsection{Affordability in the context of Water Services}

The water needs for the community must be must be fulfilled in accordance with the requirements of water security. The security of water consumed by the community can be seen from the aspect of water quality (Jalba D 2010). The Quality of water declared safe determined through conformance to the standards which set by the Clean Water Minister Regulation No 492/Menkes/Per/Iv/2010. To obtain the water quality in accordance with the standards, any water source needs to be done first processing, starting from the simplest level as screening until processing is complete. The more poor quality of the source water, the treatment process will be more complex. Obviously, this will impact the operational costs of processing.

Many factors affect the water tariff of a service. The water service system, which is managed by PDAM or private water management company, financing component in the provision of clean water including the costs of water source, processing costs, transmission costs, distribution costs, administrative expenses and personnel costs. As for the water services performed individually by non-piping services, the costs incurred in the form of electric cost for the pumps. These costs will determine the amount of water services tariff used. Inefficient conditions on one of those financing components or poor quality of water sources greatly affect the amount of water tariff.

The tariffs of water and financing to be incurred by the public can influence the affordability of water services. One of the basic principles of water services is that each water service is accessible by people with different economic level. The problem of affordability of water services is often faced by various underdeveloped and developing countries (Rita M 2010). This is often caused by an inefficient management of resources and the low value of the average income of the community.

Affordability of society for water services can be calculated based on the ratio between household income against expenses incurred for the needs of clean water (Sawkins J 2005; Reynaud, 2010; Martins R 2016). Value limit of affordability of water services in fact is not defined in absolute terms, but there is an agreement of the State or organization related to the restrictions that associated with the status and economic level of the state concerned. The value limit of affordability can be seen in Table 1. For Indonesia itself, the Government through the Minister of Home Affairs Regulation No. 23 of 2006, it has been established that limit public expenditure to meet the needs of clean water is $4 \%$ of family income. When the expenses for water exceeds $4 \%$, hence the household welfare would be jeopardized. Therefore in determining the water tariff, water services provider should take into account the magnitude of the ratio and average income levels of society. 
Table 1. Standardized Affordability Value of Water Services

\begin{tabular}{ll}
\hline Institutional administrator & Affordability Threshold Values (\%) \\
\hline Asian Development Bank & 5 \\
ERSAR (Portugal) & 3 \\
International Water Association (IWA) & 3 \\
OECD (in Eastern Europe, Caucasus, Central Asian & 4 \\
Countri & 3 (for community with the lower income) \\
United Kingdom Goverment & 3 \\
United Development Program (UNDP) & $2-2,5$ \\
United States Environmental Program (US EPA) & $3-5$ \\
World Bank &
\end{tabular}
Source: (Frankhauser S,Tepic 2007 ; Rita M 2010)

Affordability of society toward water services in some countries is the target of the government to ensure public health, enhance the dignity of State as well as improving the community welfare (El Mou Jaber 2009). The government position towards water affordability by the community reflects the contribution of government in guaranteeing the basic rights of the community. In field conditions, affordability aspect can be an obstacle for the community to meet the water needs safely (UNESCO 2015).

\subsection{Economic Conditions of Respondents}

The dominant revenue from the survey of respondents ranged from $\mathrm{Rp} 1,000,000$ - Rp 3,000,000 as many as 35.6\%. The dominant amount of monthly expenditure for $\mathrm{Rp} \mathrm{1,000,000} \mathrm{-} \mathrm{Rp} \mathrm{2,000,000} \mathrm{and} \mathrm{Rp} \mathrm{2,100,000} \mathrm{-} \mathrm{Rp} \mathrm{3,000,000}$ was $33 \%$. The average number of people in one house was 4-5. Suseda's result in 2014 shows that the average expenditure per capita population is Rp 646.843 or equivalent to Rp 2,587,374 per family. The expenditure overview per family in this result is in accordance with the result of Suseda (2014). Based on the description of economic conditions shows that the respondents' income and public expenditure is relatively balanced, thus the potential saving of monthly income is relatively low. Thus, if there are a water load increases in the community, hence the community financing burden will be higher and this would threaten the welfare of community average.

\subsection{Community's Burden For Fulfillment of The Water Needs}

Meeting the water needs for the community was carried out through a piping system that is served by PDAM and private as well as non-piping system. The water needs for the community who use non-piping system, are fulfilled by using groundwater or bulk water. The burden of public expenditure to meet the needs of water is affected by the amount of water consumed by the public itself. Water financing for the community who use the piping system issued based on monthly bill and the cost of water consumption. While the water expenditure for the people who use non-piping system comes from the purchase costs of bulk water or gallons of water as well as the cost of the electricity used to pump water.

The survey shows the number of respondents who use the piping system was $38.8 \%$ (97 respondents) and non-piping system was 61.2\% (153 respondents). Income level is classified into four parts based on the classification in the census area of Bekasi District and average incomes. The first classification is income about $<$ Rp 1,000,000, second Rp 1,000,000 - Rp 3,000,000, third Rp 3,000,000 - Rp 5,000,000 and fourth > Rp 5,000,000.

Results of a descriptive analysis of non-piping service users, it was obtained an average income between Rp $1,000,000$ - Rp 3,000,000. The average expenditure of the community to meet the water needs of Rp 87.190 per month to purchase bulk water or refill gallon. The amount of minimum monthly expenditure was Rp 0 and a maximum of $\operatorname{Rp~500,000.~People~who~spend~} \mathrm{Rp} 0$ for the water services only counting on the groundwater and do not use gallons water or other bulk water, thus their water expenditure is converted from electricity consumption for using water pump. Description of survey results can be seen in Table 2.

Table 2. Description of User Community of Non-Piping Service

\begin{tabular}{|l|l|l|l|}
\hline \multirow{2}{*}{ Parameter } & Income & Water Expenditure \\
\hline Mean & Valid & 153 & 153 \\
\cline { 2 - 4 } & Missing & 0 & 0 \\
\hline Std. Deviation & 2.5163 & 87189.5425 \\
\hline Variance & .86682 & $1.05796 \mathrm{E} 5$ \\
\hline Range & .751 & $1.119 \mathrm{E} 10$ \\
\hline Minimum & 3.00 & 500000.00 \\
\hline
\end{tabular}

The amount of expenditure for the purchase of bulk water or water gallons for people who use non-piping 
services based on the classification of family income is shown in Table 3 . The results of cross-tab analysis show that people who rely on groundwater as the only water source tend to be more dominant of 43 respondents. While the dominant expenditure for the purchase of bulk water or gallon was Rp 50,000 per month of 19 respondents, the rest is greatly varied from $\mathrm{Rp} 10,000$ - Rp 500,000 per month.

Table 3. Distribution of Water Expenditure and Community Income with Non-Piping Services

\begin{tabular}{|c|c|c|c|c|c|}
\hline \multirow[b]{2}{*}{ Water Expenditure (Rp) } & \multicolumn{4}{|c|}{ Income } & \multirow{2}{*}{ Total } \\
\hline & $<1 \mathrm{M}$ & $\mathrm{Rp} 1 \mathrm{M}-\mathrm{Rp} 3 \mathrm{M}$ & $\mathrm{Rp} 3.1 \mathrm{M}-\mathrm{Rp} 5 \mathrm{M}$ & $>\operatorname{Rp} 5 \mathrm{M}$ & \\
\hline 0 & 6 & 16 & 14 & 7 & 43 \\
\hline 10000 & 0 & 0 & 1 & 1 & 2 \\
\hline 20000 & 0 & 1 & 1 & 1 & 3 \\
\hline 25000 & 0 & 2 & 1 & 0 & 3 \\
\hline 30000 & 0 & 0 & 1 & 0 & 1 \\
\hline 35000 & 0 & 2 & 1 & 0 & 3 \\
\hline 40000 & 0 & 0 & 1 & 0 & 1 \\
\hline 45000 & 0 & 1 & 0 & 1 & 2 \\
\hline 50000 & 0 & 12 & 9 & 2 & 23 \\
\hline 60000 & 1 & 1 & 1 & 0 & 3 \\
\hline 70000 & 0 & 3 & 0 & 1 & 4 \\
\hline 75000 & 3 & 5 & 0 & 0 & 8 \\
\hline 80000 & 0 & 1 & 0 & 0 & 1 \\
\hline 85000 & 0 & 0 & 1 & 0 & 1 \\
\hline 95000 & 0 & 1 & 0 & 0 & 1 \\
\hline 100000 & 1 & 5 & 4 & 1 & 11 \\
\hline 120000 & 0 & 1 & 1 & 0 & 2 \\
\hline 125000 & 0 & 0 & 1 & 0 & 1 \\
\hline 150000 & 4 & 5 & 6 & 4 & 19 \\
\hline 175000 & 0 & 1 & 0 & 0 & 1 \\
\hline 180000 & 1 & 0 & 0 & 0 & 1 \\
\hline 200000 & 0 & 2 & 5 & 1 & 8 \\
\hline 230000 & 0 & 0 & 0 & 1 & 1 \\
\hline 250000 & 0 & 2 & 0 & 0 & 2 \\
\hline 300000 & 0 & 1 & 1 & 0 & 2 \\
\hline 350000 & 0 & 0 & 0 & 1 & 1 \\
\hline 500000 & 0 & 2 & 2 & 1 & 5 \\
\hline Total & 16 & 64 & 51 & 22 & 153 \\
\hline
\end{tabular}

Expenditure load to meet the water needs of the community who utilize bulk water or gallon water can be seen in Table 4. Based on income variations, the highest average expenditure comes from income group $>$ US $\$ 5,000,000$ of Rp 101.136 per month, it is influenced by an increase in water consumption. While expenditure for meeting water needs come from the lowest income group $=<\mathrm{Rp} 1,000,000$ of $\mathrm{Rp} 72.813$ per month. From the terms of water expenditure proportion to the family income, then the household who have an income $<$ Rp $1,000,000$ has the water load expenditure is higher than other income groups. Expenses for water expenditure for community who has an income $<$ USD 1,000,000 and Rp 1,000,000 - Rp 3,000,000 has exceeded the determined water load by Permendagri of $4 \%$.

Table 4. Average Air Expenditure Based on Revenue of Non-Piping Service

\begin{tabular}{|l|c|c|c|c|}
\hline \multirow{2}{*}{\multicolumn{1}{c|}{ Component }} & \multicolumn{4}{|c|}{ Income } \\
\cline { 2 - 5 } & $<1 \mathrm{M}$ & $\mathrm{Rp} \mathrm{1} \mathrm{M} \mathrm{-} \mathrm{Rp} \mathrm{3} \mathrm{M}$ & $\mathrm{Rp} \mathrm{3.1} \mathrm{M} \mathrm{-} \mathrm{Rp} \mathrm{5} \mathrm{M}$ & $>\mathrm{Rp} \mathrm{5} \mathrm{M}$ \\
\hline Average Water Consumption & 72.813 & 83.594 & 90.196 & 101.136 \\
\hline Water Load & 7.28 & $2.9-8.36$ & $1.8-2.91$ & 2.2 \\
\hline
\end{tabular}

Water expenditure cost for the community who use pump on their well is calculated from the estimation of electric usage for the water pump. To estimate the power consumption due to the use of an electric pump, it is used assumptions that set based on the price during this research. The assumptions are:

a. Water pumps used have an average of 125 watts of electrical specifications, 1.2 amperes and 220-volt pump capacity of 29 liters/minute

b. The price of pumping machine with these specifications in 2016 have an average price of $\operatorname{Rp} 450,000$

c. Maintenance costs for a period of 3 years on average Rp 100,000 (for impeller replacement)

d. Electricity tariff average of Rp 1,459.74 per KWH

e. Water consumption of 90 liters/person/day, if the householder has average of 5 people, then the water 
consumption per day would be 90 liters/person/day x $5=450$ liters/day

Based on the assumptions above, it can be calculated:

a. Operation time of pump

Water volume needed

Operation time of pump =

$\frac{-15,5 \text { minute }}{29 \text { liter/minute }}$

$$
\begin{aligned}
& \text { Actual capacity of pump } \\
& \begin{array}{l}
450 \text { liter } \\
=15,5 \text { minute } \\
\hline 29 \text { liter/minute }
\end{array}
\end{aligned}
$$

b. Electricity consumption for pump per day

Electricity consumption per day $=$ electical power $\mathrm{x}$ power factor $\mathrm{x}$ usage time

$$
=125 \text { watt } \times 0,8 \times(15,5 \text { menit } / 60 \text { minutes/hour })
$$$$
=26 \text { watt } \approx 0.26 \mathrm{KWH}
$$

c. Electricity consumption for pump per month

Electricity consumption per month = daily electricity consumption $\mathrm{x} 30$ days $/$ month

$$
=0,26 \mathrm{KWH} \times 30 \text { days } / \text { month }=7.8 \mathrm{KWH} / \text { month }
$$

d. The procurement cost of water pumps and its maintenance within 3 years

The procurement cost of pump $=$ purchase price of pump + maintenance cost

$$
\begin{aligned}
& =\operatorname{Rp} 450,000+\operatorname{Rp} 100,000 \\
& =\operatorname{Rp} 550,000 \text { for } 3 \text { years } \\
& =\operatorname{Rp~} 15,278 \text { per month }
\end{aligned}
$$

e. The electricity cost for pump

The electricity cost = electricity consumption $\mathrm{x}$ electricity cost $/ \mathrm{KWH}$

$$
\begin{aligned}
& =7.8 \mathrm{KWH} \times \mathrm{Rp} 1,459.74 / \mathrm{KWH} \\
& =\operatorname{Rp} 11,389
\end{aligned}
$$

f. The cost of total water expenditure

Water procurement cost $=$ electricity cost + pumping cost

$$
\begin{aligned}
& =\operatorname{Rp} 11,389+\operatorname{Rp} 15,278 \\
& =\operatorname{Rp} 26,667
\end{aligned}
$$

Based on the calculation of load expenditure for community who use the water pump based on income variations is as follows:

a. Income of $<\operatorname{Rp} 1.000 .000=>2,67 \%$

b. Income of $\operatorname{Rp~} 1.000 .000-\operatorname{Rp} 3.000 .000=0,89 \%-2,67 \%$

c. Income of $\operatorname{Rp~} 3.100 .000-\operatorname{Rp} 5.000 .000=0,53 \%-0.89 \%$

d. Income of $>\operatorname{Rp} 5.000 .000=<0,53 \%$

The calculations show that a load of water expenditure on non-piping service, for people who use groundwater with a pump is lower than people who buy bulk water and gallon. In a variety of revenue, the load expenditure to meet the water needs of is still below the threshold value that set by Regulation No. 23 of 2006 of $4 \%$.

Description of survey results for people who use the piping service, it is obtained an average income between $\mathrm{Rp} 3,000,000$ - Rp 5,000,000. The average expenditure of the community to meet the water needs of $\mathrm{Rp} 147.928$ per month, both in served by PDAM and private PAM. The minimum and maximum expenditure per month were Rp 30,000 and Rp 400,000, respectively. Description of the survey results can be seen in Table 5.

Table 5. Survey Result Description of Piping Service System

\begin{tabular}{|l|l|l|l|}
\hline Parameter & Pendapatan & Pengeluaran_air \\
\hline $\mathrm{N}$ & Valid & 97 & 97 \\
\hline & Missing & 0 & 0 \\
\hline Mean & & 2,9381 & 147927,8351 \\
\hline Std. Deviation & & 0,95541 & 75607,57339 \\
\hline Variance & & 0,913 & $5,72 \mathrm{E}+09$ \\
\hline Minimum & & 1 & 30000 \\
\hline Maximum & & 4 & 400000 \\
\hline
\end{tabular}

The amount of expenditure for payment of monthly water bill is based on people's income classification can be seen in Table 6 . The results of cross-tab analysis show that people who use water services are likely in upper middle-income, with the number of respondents that are in the dominant income $>\operatorname{Rp} 5,000,000$ of 35 respondents. While the dominant expenditure for payment of the water bill of Rp 100,000 and Rp 200,000 per month were 23 and 22 respondents, respectively. As the rest is greatly varied between $\mathrm{Rp} 30,000$ - Rp 400,000 per month. 
Table 6. Distribution of Water Expenditure and Community Income With Non-Piping Services

\begin{tabular}{|c|c|c|c|c|c|}
\hline \multirow{2}{*}{$\begin{array}{l}\text { Expenditure } \\
\text { (Rp) }\end{array}$} & \multicolumn{4}{|c|}{ Income } & \multirow[b]{2}{*}{ TOTAL } \\
\hline & $<\operatorname{Rp} 1 \mathrm{M}$ & $\operatorname{Rp} 1 \mathrm{M}-\operatorname{Rp} 3 \mathrm{M}$ & Rp 3.1 M - Rp 5 M & $>\operatorname{Rp} 5 \mathrm{M}$ & \\
\hline 30,000 & 0 & 0 & 1 & 0 & 1 \\
\hline 50,000 & 2 & 1 & 3 & 3 & 9 \\
\hline 60,000 & 0 & 0 & 1 & 0 & 1 \\
\hline 70,000 & 0 & 2 & 0 & 0 & 2 \\
\hline 75,000 & 0 & 1 & 0 & 1 & 2 \\
\hline 80,000 & 0 & 1 & 0 & 0 & 1 \\
\hline 85,000 & 1 & 0 & 1 & 0 & 2 \\
\hline 99,000 & 0 & 1 & 0 & 0 & 1 \\
\hline 100,000 & 1 & 9 & 5 & 8 & 23 \\
\hline 120,000 & 0 & 2 & 2 & 1 & 5 \\
\hline 150,000 & 1 & 4 & 5 & 6 & 16 \\
\hline 200,000 & 0 & 6 & 9 & 7 & 22 \\
\hline 210,000 & 0 & 0 & 0 & 2 & 2 \\
\hline 250,000 & 0 & 2 & 0 & 2 & 4 \\
\hline 300,000 & 1 & 0 & 0 & 2 & 3 \\
\hline 350,000 & 0 & 0 & 0 & 1 & 1 \\
\hline 400,000 & 0 & 0 & 0 & 2 & 2 \\
\hline Total & 6 & 29 & 27 & 35 & 97 \\
\hline
\end{tabular}

Expenditure load to meet the water needs of the community who use the piping service system can be seen in Table 7. Based on the variety of income groups, the highest average expenditure comes from revenue group $>$ $\mathrm{Rp} 5,000,000$ in the amount of $\mathrm{Rp} 174,714$ per month. This is influenced by the Increase in water consumption and water tariff, in which upper-middle-class community has the expense of the water tariff that is already full cost recovery (FCR). While expenditure for fulfillment the water needs comes from the lowest income group of $<$ Rp 1,000,000 was Rp 122,500 per month. From the water expenditure proportion to the family income, the

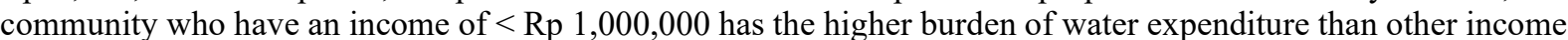
groups. Water Expenditure for all income groups has to be above the threshold values that is set out in Regulation No 23 of 2006 of 4\%, unless for the community who can earn the income $>$ Rp 5,000,000.

Table 7. Average Water Expenditure and Community Income With Non-Piping Services

\begin{tabular}{|l|l|l|c|l|}
\hline \multirow{2}{*}{ Criteria } & Income & Rp 1 M - Rp 3 M & Rp 3.1 M - Rp 5 M & $>\operatorname{Rp~5~M~}$ \\
\cline { 2 - 5 } & $<\mathrm{Rp} \mathrm{1} \mathrm{M}$ & 133.931 & 133.889 & 174.714 \\
\hline Expenditure (Rp) & 122.500 & $4.46-13.39$ & $2.68-4.32$ & 3.49 \\
\hline Water Load (\%) & 12.25 & &
\end{tabular}

Expenditure load for the water can affect people's choice of the water service to be used. With this phenomenon, it will give a tendency to residents, especially for low-income communities to use non-piping service system. The option of non-piping service system gives a risk for people to obtain water that does not meet the requirements of quality, quantity, and continuity, or in other words, it is not safe for the community. For the uppermiddle income community, piping service system can be unappealing if the quality of services such as quality, quantity, and continuity of water can not be guaranteed by PDAM. Therefore, to alleviate the burden on the community in the term of water expenditure and to ensure the water quality is safe, the government should control the price of water thus as not to burden the people. So, it is necessary to evaluate the financing structure and technical processes in PDAM to avoid inefficiencies, improve and ensure the quality of surface water as a source of raw water PAM as well as in improving macro-scale economic ability.

\section{CONCLUSSION}

Expenditure to meet water needs for people in Bekasi District who use piping service is relatively higher compared to people who use non-piping service. Only piping service users with income $>$ Rp 3,100,000 per month have the water fulfillment that is still in accordance with the maximum load that is set by Government Regulation No. 23/2006. This condition can predispose people that have middle-lower income in order to avoid the use of piping service unless they have no other choice in water sources. This has an impact on several things including (1) the growth of connections is relatively low, (2) the exploitation of ground water resources, (3) lack of quality assurance of the water consumed by people, (4) the threat to the welfare of community. It also occured on people who use non-piping service that do not use groundwater or people who use the bulk water or refill gallon. Income community of $<\operatorname{Rp} 3,000,000$ per month have to bear the burden of water expenditure that is greater, thus it can threaten their welfare.

To improve water services in Bekasi and reduce the burden on low-income people, hence it is necessary to 
do multiple efforts including: (1) evaluation of tariff and allocation system of PDAM tariff, (2) evaluation of PDAM performance in order to reduce operational costs, (3) Improved quality of service PDAM both in terms of quality, quantity and continuity of the supply system , (4) improve the quality of surface water, thus it can be utilized by PDAM as raw water, in order to improve the supply and reduce the processing cost, (5) review the mastery of springs or water sources by the private sector or individuals, because the trends can be exploited economically, (6) forming UPTD (technical executing unit area) which organizes a simple water treatment in the area of low-income communities (MBR).

\section{References}

Clasen T, P.-U. A, (2014), "Estimating the impact of unsafe water, sanitation, hygiene on the burden of disease: evolving and alternative methods", Trop.Med.Int. Health 19(8), 884-893.

El Mou Jaber, M. d.-L, (2009), "Technologies perspectives for Rational use of water resource in Mediterranean Region”, Mediterraneennes: Serie A Seminaires Mediterraneens , pp. 57-68.

Frankhauser S.T. S, (2008), "Can Poor Consumers Pay for Energy and Water ? An Affordability, subsidies and arrears". Energy Policy 36 (11), 4168-4177.

Hunter P R, M. D. (2010), "Water Supply and health,. Plos Med 7(11) .

Irawan, B, (2009), "Willingness to Pay and Ability to Pay Household Customers in Response to PDAM Water Services of Local Water Company (PDAM) Kota Surakarta". Jejak 2(1).

Jalba D. N. J, (2010). "Safe drinking: Critical components of effective inter-agency reletionship", Environmental International, 51-59.

Lee E J. S. K, (2005), "Deficiencies in drinking water distrubution system in developing countries", Journal Water Health 3(2), 109-127.

Pinto F S, F. J, (2015), “A multi-objective approach with soft constraints for water supply and wastewater coverage improvement”, Europen Journal of Operational Research , 1-10.

Rita M, C. Q, (2010), "Water affordability issue in developed countries - The relevance of Micro approach", Utilities Policy, 1-7.

Sawkins J, D. V, (2005), “Affordability of household water service in great Britain”, Water Environ. 19, 207-213. UNESCO, (2015), “Water for Sustainable World,. Paris: United Nations Educational, Scientific and Cultural Organization. 